\title{
On the Mechanism of Acetylcholine Receptor Accumulation at Newly Formed Synapses on Chick Myotubes ${ }^{1}$
}

\author{
LORNA W. ROLE, ${ }^{2}$ VIKEN R. MATOSSIAN, RICHARD J. O'BRIEN, ${ }^{3}$ AND GERALD D. FISCHBACH ${ }^{4}$
}

Department of Anatomy and Neurobiology, Washington University School of Medicine, Sl. Louis, Missouri 63110

\begin{abstract}
We have examined the specificity and the mechanism of acetylcholine receptor (AChR) accumulation at embryonic chick nerve-muscle contacts that form in culture. Spinal cord motoneurons were identified in vitro after labeling them in vivo with Lucifer Yellow-wheat germ agglutinin conjugates. All of their processes induced receptor clusters on contacted myotubes; after 24 to $48 \mathrm{hr}$ of co-culture, the incidence of neurite-associated receptor patches (NARPs) was $\sim 1.2 / 100$ $\mu \mathrm{m}$ of contact. In contrast, NARPs were rarely associated with spinal cord interneurons $(\sim 0.1 / 100 \mu \mathrm{m}$ of contact).

Neurons dissociated from ciliary ganglia induce NARPS to the same extent as motoneurons. The relative contribution to NARPs of AChRs present in the membrane prior to plating ciliary ganglion neurons and of "new" AChRs inserted 8, 11, or $17 \mathrm{hr}$ after addition of neurons was assessed with two fluorescent receptor probes. Rhodamine-conjugated $\alpha$-bungarotoxin was used to label either old or new receptors; a monoclonal, anti-receptor antibody visualized with fluorescein-second antibody was used to label all (new and old) receptors. Analysis of digitized fluorescence images showed that NARPs contained both new and old receptors but that within the first $24 \mathrm{hr}$ of co-culture the majority (60 to $80 \%$ ) were new. We estimate that cholinergic neurites increase the rate of receptor insertion 4- to 5-fold during the first $8 \mathrm{hr}$ of NARP formation. The contribution of new receptors to NARPs declines with time. After 3 days of co-culture, receptors inserted over an 8-hr interval comprised only $20 \%$ of the total NARP complement. Receptor clusters that appear beneath or adjacent to neuron cell-myotube contacts are apparently different from NARPs in that the contribution of newly inserted clusters never exceeded $\sim 20 \%$ of the total even during the first $24 \mathrm{hr}$ of co-culture. Thus, the relative importance for NARP formation of receptor migration within the
\end{abstract}

Received September 20, 1984; Revised January 7, 1985:

Accepted January 14, 1985

\footnotetext{
1 This work was supported by United States Public Health Service Grant NS 18458 (G. D. F.), and by National institutes of Health Postdoctoral Fellowship F32NSO6710 (L. W. R.) and Training Grant GM07306 (R. O.). We are grateful to Dr. Jon Lindstrom for providing the essentıal antı-receptor antibody (Mab 35). Dr. Julia Matthews-Bellinger participated in preliminary experiments.

2 Present address: Department of Anatomy and Cell Biology, Columbia University, College of Physicians and Surgeons, 630 West 168th Street, New York, NY 10032.

${ }^{3}$ Present address: Department of Pharmacology, Harvard Medical School, 250 Longwood Avenue. Boston, MA 02115.

${ }^{4}$ To whom correspondence should be addressed
}

membrane and of receptor insertion varies with time and position along the cell body-neurite axis.

Synaptic potentials can be evoked within a few minutes after a cholinergic growth cone contacts an uninnervated muscle cell in vitro (Cohen, 1980; Kidokoro and Yeh, 1982; Role et al., 1983), and acetylcholine receptors (AChRs) accumulate in the postsynaptic membrane a few hours thereafter (Anderson et al., 1977; Frank and Fischbach, 1979). The receptor density within neurite-associated receptor patches (NARPs) is more than 10 times the receptor density within the nearby extrasynaptic membrane (Fischbach and Cohen, 1973). Uninnervated myotubes contain a few high density receptor aggregates, but these "hot spots" represent a small fraction of the total membrane area and they are not sought out by ingrowing axons. NARPS represent new, induced clusters (Anderson and Cohen, 1977; Frank and Fischbach, 1979).

Little is known concerning the specificity of the nerve-muscle interaction that leads to AChR accumulation. Sensory ganglion neurons, which presumably are noncholinergic in vitro, do not induce NARPs on Xenopus muscle cells (Cohen and Weldon, 1980) or on chick myotubes, but the degree of specificity within the population of spinal cord cells has not been examined. We have labeled motoneurons in vivo with a retrogradely transported fluorescent probe (Okun, 1981) and have identified them after several days in culture to compare them with the unlabeled interneurons in regard to AChR accumulation.

Also, little is known concerning the mechanism of receptor accumulation at newly formed synapses. AChRs in embryonic myotubes are synthesized and degraded rapidly (half-life of 20 to $24 \mathrm{hr}$ ) (Devreotes and Fambrough, 1975; Devrcotes et al., 1977; Gardner and Fambrough, 1979), and they are mobile within the lipid bilayer (Axelrod et al., 1976; Orida and Poo, 1978). In principle, therefore, NARPs might form by insertion of newly synthesized receptors, or by migration of "old" receptors exposed on the surface prior to nervemuscle contact. By labeling Xenopus myocyte receptors with rhodamine-conjugated $\alpha$-bungarotoxin (R-BTX) prior to addition of neurons, Anderson and Cohen (1977) demonstrated that, in this species, old receptors do migrate to sites of nerve-muscle contact, but the contribution of newly synthesized receptors was not determined. No information is available concerning the relative contribution of preexisting and newly synthesized receptors to the formation of NARPS in vitro in other species.

A better understanding of the mechanism of AChR accumulation at different stages of development is important for further cellular and molecular analyses of synapse formation. For example, attempts are underway to purify molecules present in neural tissue, neuron conditioned medium, and preparations of extracellular matrix that mimic the effect of motor nerves on receptor accumulation (Christian et al., 1978; Podleski et al., 1978; Jessell et al., 1979; Buc-Caron et al., 1983; Nitkin et al., 1983). The bioassay is crucial: should one measure receptor synthesis, receptor aggregation, or both? We 
show here, by analyzing digitized images of fluorescently tagged receptors, that both old and new receptors contribute to NARPS induced by cholinergic neurons on chick myotubes, but that at early times, new receptors predominate. The contribution of new receptors is too high to be accounted for by the "basal" rate of receptor synthesis and insertion. Some of these results have been reported in abstract form (Fischbach et al., 1984).

\section{Materials and Methods}

Myoblasts were dissociated from pectoral muscles of 11-day chick em bryos and grown in culture as previously described (Fischbach, 1972). Cells were plated on collagen-coated glass coverslips and fed with Eagle's minimum essential medium (MEM) supplemented with heat-inactivated horse serum $(10 \% \mathrm{v} / \mathrm{v})$ and chick embryo extract $(2 \%, v / v)$. Fibroblasts were eliminated by addition of $10^{-5} \mathrm{M}$ arabinosylcytosine (araC) to the medium for $24 \mathrm{hr}$ beginning on the third day after plating. Spinal cord cells, dissociated trom 6-day embryos, were added to multinucleated myotubes after removal of araC. One day prior to dissection of the spinal cords, motoneurons were labeled by retrograde transport of Lucifer Yellow-vinyl sulfone-wheat germ agglutinin conjugates (LY.WGA; Stewart, 1981). Our technique was similar to that described by Okun (McPheeters and Okun, 1980; Okun, 1981), and it will be described in detail in a subsequent publication (R. J. O'Brien and G. D. Fischbach, manuscript in preparation). In brief, a hole was cut in the egg shell and the hindlimb was drawn through a slit in the chorioallantoic membrane, and LY.WGA was pressure injected at multiple sites in the thigh and shank. The egg was then sealed and returned to the incubator for 24 $\mathrm{hr}$. The cultures were examined and tested on the stage of an inverted microscope (Leitz Diavert) equipped with epifluorescence illumination, a $\times 40$ phase contrast objective (numerical aperture $=1.3$ ), and filters selective for rhodamine (N2; E:530 to $560 \mathrm{~B}: 580$ ) and fluorescein (G; E:350 to $460 \mathrm{~B}: 515$ ) Ciliary ganglion neurons were dissociated from 8- to 9-day embryos and plated according to techniques described by Nishi and Berg (1977).

The entire neuritic arbor of individual motor neurons or ciliary ganglion neurons was visualized by injecting cell bodies with Lucifer Yellow CH (LY) Microelectrodes were filled with a $4 \%$ solution of $L Y$ in $0.25 \mathrm{M} \mathrm{LiCl}$, and the dye was injected for 2 to $5 \mathrm{~min}$ with negative pulses $1 \mathrm{sec}$ in duration repeated at $0.5 \mathrm{~Hz}$.

NARPs and hot spots were visualized with two labels. R-BTX was prepared according to the method of Ravdin and Axelrod (1977). The R-BTX was titrated to find conditions that labeled all exposed receptors by adding it to cultures at several concentrations for $1 \mathrm{hr}$ at $37^{\circ} \mathrm{C}$. The concentration beyond which fluorescence intensity did not increase was determined, and in al experiments, R-BTX was added at 2 times this saturating level. Receptors were also labeled with a rat monoclonal antibody directed against an extracellular part of the $\alpha$ subunit of the receptor (Mab 35, kindly provided by J. Lindstrom of the Salk Institute). The ammonium sulfate-precipitated hybridoma supernatant, when resuspended in saline, had an anti-Torpedo AChR titer of $4.2 \times 10^{-5} \mathrm{M}$. A 1:600 dilution was added to the cultures in MEM plus $10 \%$ horse serum for $1 \mathrm{hr}$ at $37^{\circ} \mathrm{C}$. Higher concentrations did not increase the intensity of NARP tluorescence. Mab 35 was visualized with fluorescein-conjugated goat anti-rat antibodies ( $F$-GAR; also provided by $\mathrm{J}$ Lindstrom). The affinity-purified GAR was $4.3 \times 10^{-5} \mathrm{M}$ in lg. It was added at a 1:600 dilution for $30 \mathrm{~min}$ at $37^{\circ} \mathrm{C}$. The coverslip cultures were washed in phosphate-buffered saline (PBS) plus sucrose $(100 \mathrm{~mm})$, fixed in $4 \%$ para formaldehyde, and mounted on glass slides in $90 \%$ glycerol. The fluorescence intensity of labeled AChR clusters was evaluated with a Dage SIT television camera connected to a Grinnell GMR/270 Image Processor inter faced to a PDP 11/44 computer. In these experiments an upright microscope with $a \times 63$ phase contrast (numerical aperture $=1.4$ ) objective was used. A sensitive photometer (Leitz MPV-3) was used to determine that the output of the camera and the Grinnell image processor was linear over a 16-fold range of brightness that included most of the NARPs labeled with rhodamine or fluorescein. A neutral density filter was used when exceptionally bright NARPS generated signals outside of this range.

In some experiments we determined the rate of receptor insertion in uninnervated myotubes as described by Devreotes and Fambrough (1975) Myotubes were grown alone (without added neurons) in 96-well plates under conditions identical to those described above. Surface receptors were blocked with native $\left(\mathrm{r}\right.$-bungarotoxin $\left(\mathrm{c}\right.$-BTX) $\left(10^{-7} \mathrm{M}, 37^{\circ} \mathrm{C}\right.$ for $\left.1 \mathrm{hr}\right)$, and then new receptors incorporated in the membrane were labeled by incubation with $1 \mathrm{~nm}{ }^{125}$-BTX (mono-iodo BTX; specific activity, $1500 \mathrm{cpm} / \mathrm{fmol}$; kindly provided by 1 . Usdin) atter 8,11 , or $1 / \mathrm{hr}$ at $37^{\circ} \mathrm{C}$. The number of surface receptors was assessed as previously described (Buc-Caron et al., 1983).
Nonspecific binding was determined in cultures incubated with $10^{-9} \mathrm{M}^{125}$ BTX plus $10^{-7} \mathrm{M} \alpha \cdot \mathrm{BTX}$

\section{Results}

The specificity of NARP induction was tested in spinal cord muscle cultures by examination of R BTX staincd NARPs along the course of LY-injected neurites. A cell was considered a motoneuron if it contained numerous brightly fluorescent granules when viewed with an appropriate filter (Fig. 1, inset). Once identified, each motoneuron was injected with LY so that neurites could be traced to their fine terminals even when they passed beneath refractile musclo fibcrs or formed fascicles with other nerve processes. After 2 to 3 days of co-culture, all but one of the 21 motoneurons examined induced NARPs on contacted myotubes. In most cases, bright patches of R-BTX fluorescence were observed along each of the major processes that issued from the multipolar motoneurons (Fig. 1). Thus, NARP induction cannot be used to distinguish axons from dendrites in vitro. In contrast to the motoneurons, only 3 of 21 non-motoneurons were associated with NARPS. Neurites of motoneurons were usually associated with several NARPs, but none of the four "positive" non-motoneurons were associated with more than one receptor cluster. Whe the neuritic arbor was linearized with the aid of a digitizing tablet, motoneurons were found to have 15-fold more NARPs/100 $\mu \mathrm{m}$ of nerve-muscle contact $(1.2 / 100 \mu \mathrm{m} ; 10$ neurons; $\sim 4700 \mu \mathrm{m}$ of contact) than did non-motoneurons in the same cultures $(.07 / 100 \mu \mathrm{m} ; 21$ neurons; $\sim 5000 \mu \mathrm{m}$ of contact)

Ciliary ganglion neurons, many of which innervate striated muscle in the chick iris, also induced NARPs in culture (Role et al., 1983). These cells are unipolar in adult ganglia, and, with time they become unipolar in culture (L. W. Role and G. D. Fischbach, manuscript in preparation). However, for the first few days after plating, the period examined in these experiments, they were multipolar, and as observed with motoneurons, each of the major processes issuing from a cell body induced NARPs. The mean NARP density along ciliary neurites (1.2/100 $\mu \mathrm{m} ; 14$ neurons; $\sim 5200 \mu \mathrm{m}$ of contact) was identical to that observed along motoneuron processes at the same time in culture

The time course and mechanism of NARP induction were studied in more detail using ciliary ganglion neurons rather than motoneurons because, under our culture conditions, they extend processes more rapidly and more reliably during the first few hours after dissociation. The number of NARPs per ciliary neuron was determined for 54 cells between $4 \mathrm{hr}$ and 9 days after plating (Fig. 2). The number of NARPs per cell increased rapidly over the first $24 \mathrm{hr}$ and then more slowly to a stable plateau observed after 3 days. Between 8 and $17 \mathrm{hr}$, NARPs were relatively infrequent, but they could be identified unambiguously. At this time, they contained several bright "speckles" distributed over a relatively wide area as compared to the more compact NARPs observed after 3 days of co culturc (Fig. 3).

We examined the mechanism of NARP formation during the first $24 \mathrm{hr}$ of co-culture, the period of rapid induction. The contribution to NARPs of "old" receptors, exposed on the surface prior to addition of neurons, and of new receptors, inserted after addition of the neurons, was determined as follows. In one series of experiments, all exposed receptors were labeled with R-BTX (see "Materials and Methods"). the R-BTX was then washed out and neurons were plated in the presence of $10^{-7} \mathrm{M}$ unconjugated $\mathrm{BTX}$ to prevent the binding of residual R-BTX. After 8,11 , or $17 \mathrm{hr}$, all receptors (old and new) were labeled with Mab 35 which was visualized with $F$. GAR. We took the ratio of rhodamine to fluorescein intensity as the measure of the relative contribution of old receptors. The proportion of new receptors was obtained by subtraction. Control cultures were labeled simultaneously with R-BTX and Mab 35 at the indicated times, and this rhodamine/fluorescein ratio was used to normalize the ratio obtained in experimental cultures. Background values, for both rhodamine and fluorescein, were subtracted in each case. Background usually amounted to 0.1 to 0.2 of peak values. Peak values less than 2 times background were excluded. In a comple- 


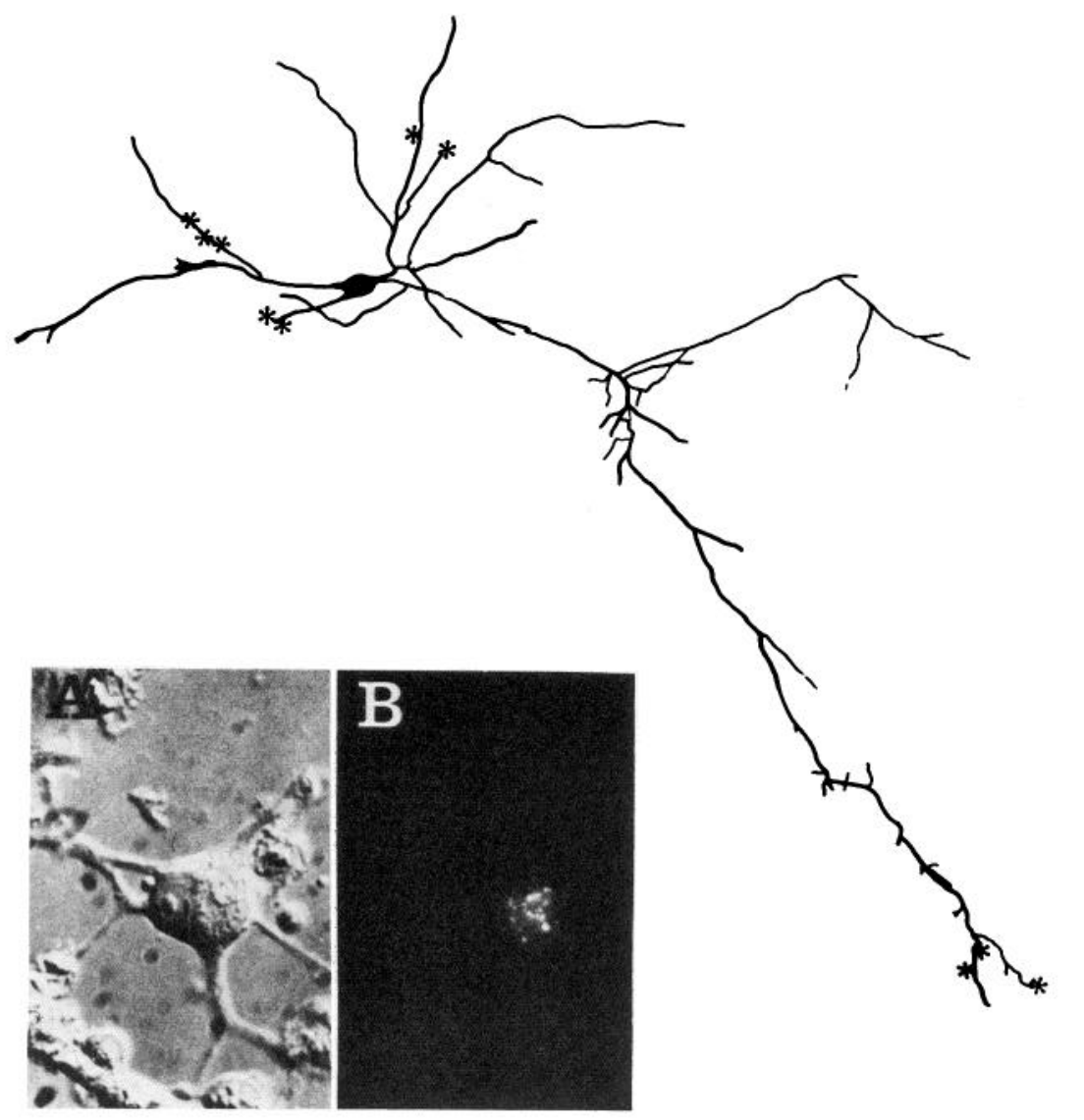

Figure 1. A tracing of a motoneuron (injected with $L Y$ ). Asterisks indicate the position of R-BTX patches (NARPS) on contacted myotubes (not shown). Motoneurons were labeled in vivo by retrograde transport of LY-WGA and were identified in vitro by the presence of punctate fluorescence within the soma (inset). $A$, contrast. $B$, fluorescence illumination.

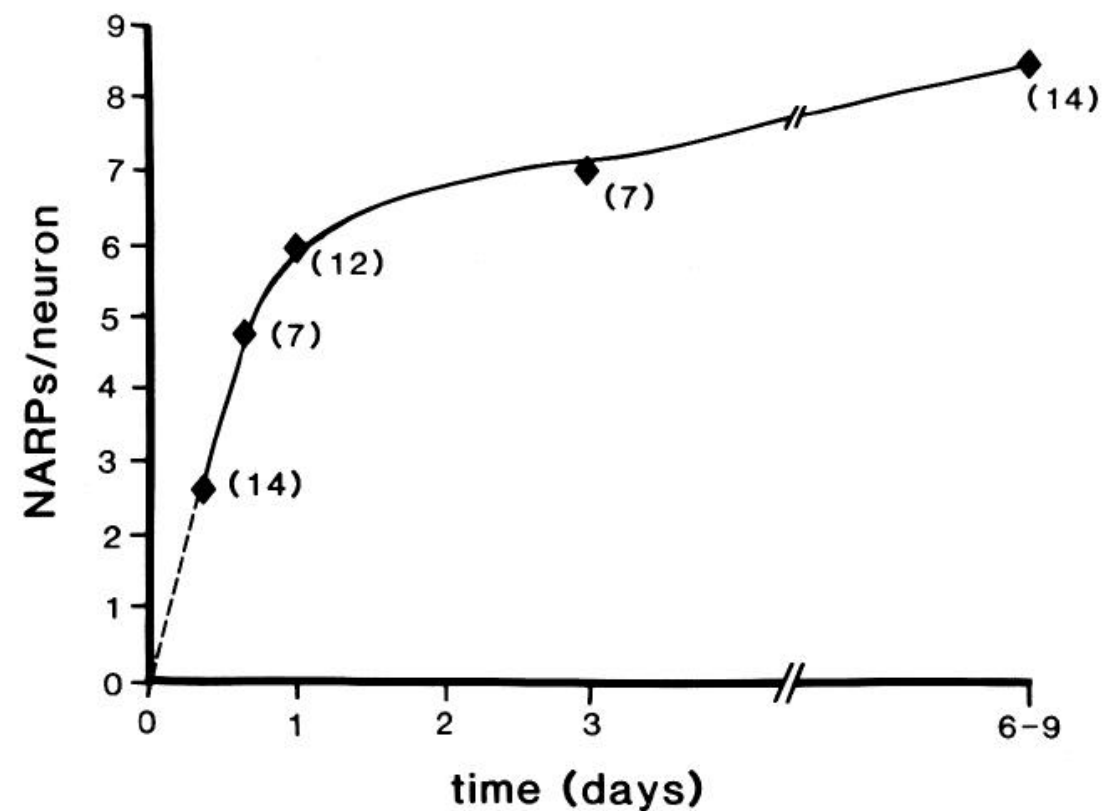

Figure 2. The time course of NARP induction by ciliary ganglion neurons. The number of NARPs per neuron was assessed for 54 ciliary ganglion neurons between $4 \mathrm{hr}$ and 9 days of co-culture with myotubes. NARPs were visualized as R-BTX-stained patches of fluorescence beneath LY-filled neuritic processes as described in the text.

mentary series, all receptors were labeled with unconjugated BTX $\left(10^{-7} \mathrm{M}, 1 \mathrm{hr}, 37^{\circ} \mathrm{C}\right)$, and then the neurons were plated in the presence of R-BTX. After labeling at the end of the incubation period with the monoclonal antibody, the ratio of R-BTX to F-GAR fluorescence provided a measure of the proportion of newly inserted receptors, and the difference indicated the contribution of old receptors.

The intensity of fluorescence was quantitated with the SIT cameraGrinnell-PDP 11/44 system. An interactive computer program was used to enlarge each NARP so that it occupied a significant part of the $512 \times 512$ pixel array. In this manner, the intensity of more than approximately 1000 points within a selected NARP was measured with 8 bits of resolution. The intensity of rhodamine and fluorescein fluorescence varied significantly at different points within each NARP, but the ratio of rhodamine to fluorescein was constant (Fig. 4). We based our calculations on the rhodamine/fluorescein ratio after background subtraction at the region of maximum intensity which usually included about 50 pixels.

Figure 5 shows that the detection system could measure small changes in fluorescence. In this experiment, we measured the 

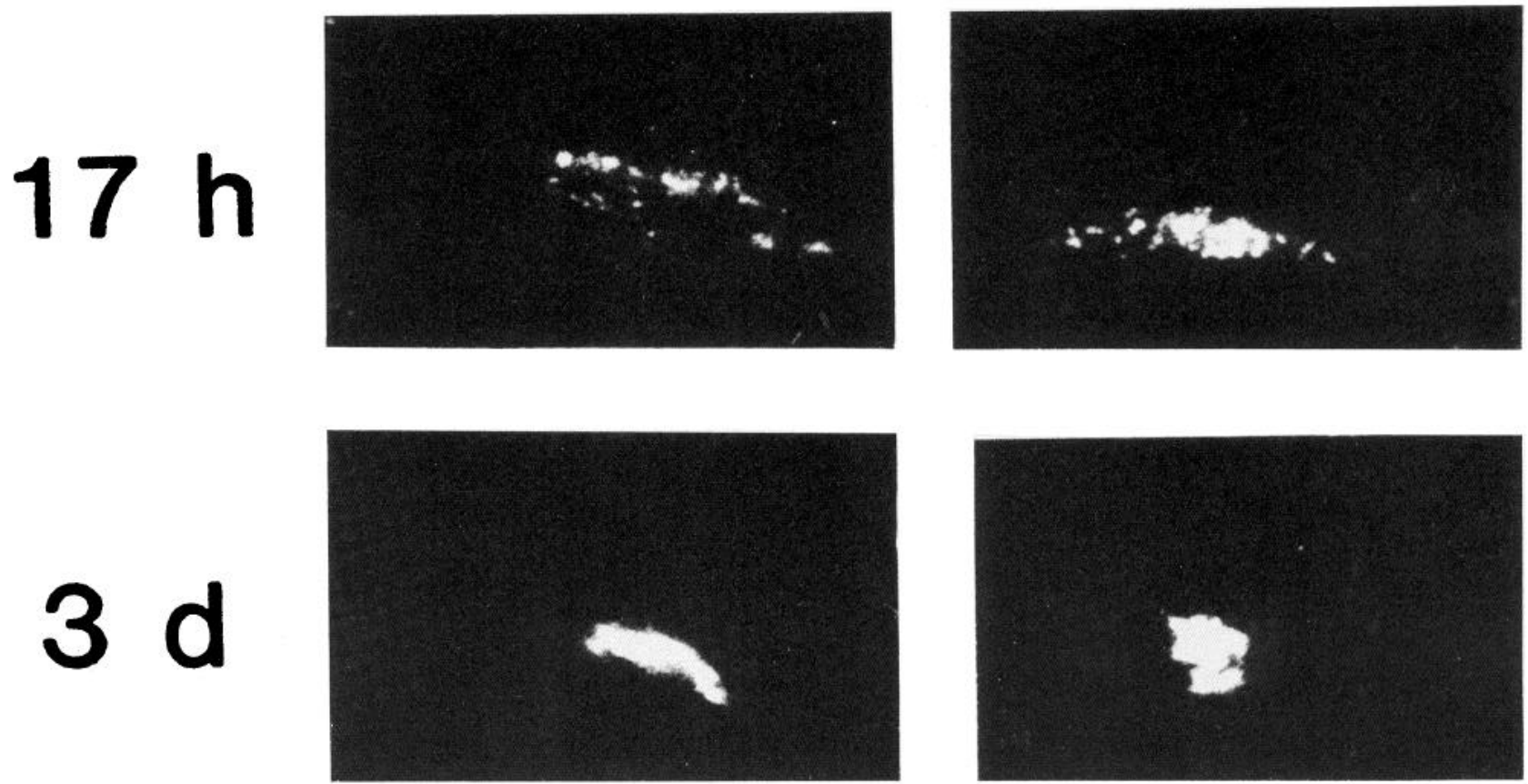

Figure 3. The appearance of 17-hr and 3-day NARPs. Note that early NARPs are more diffuse and are comprised of several bright speckles of fluorescence, whereas older NARPs appear as more condensed streaks or patches of fluorescence.
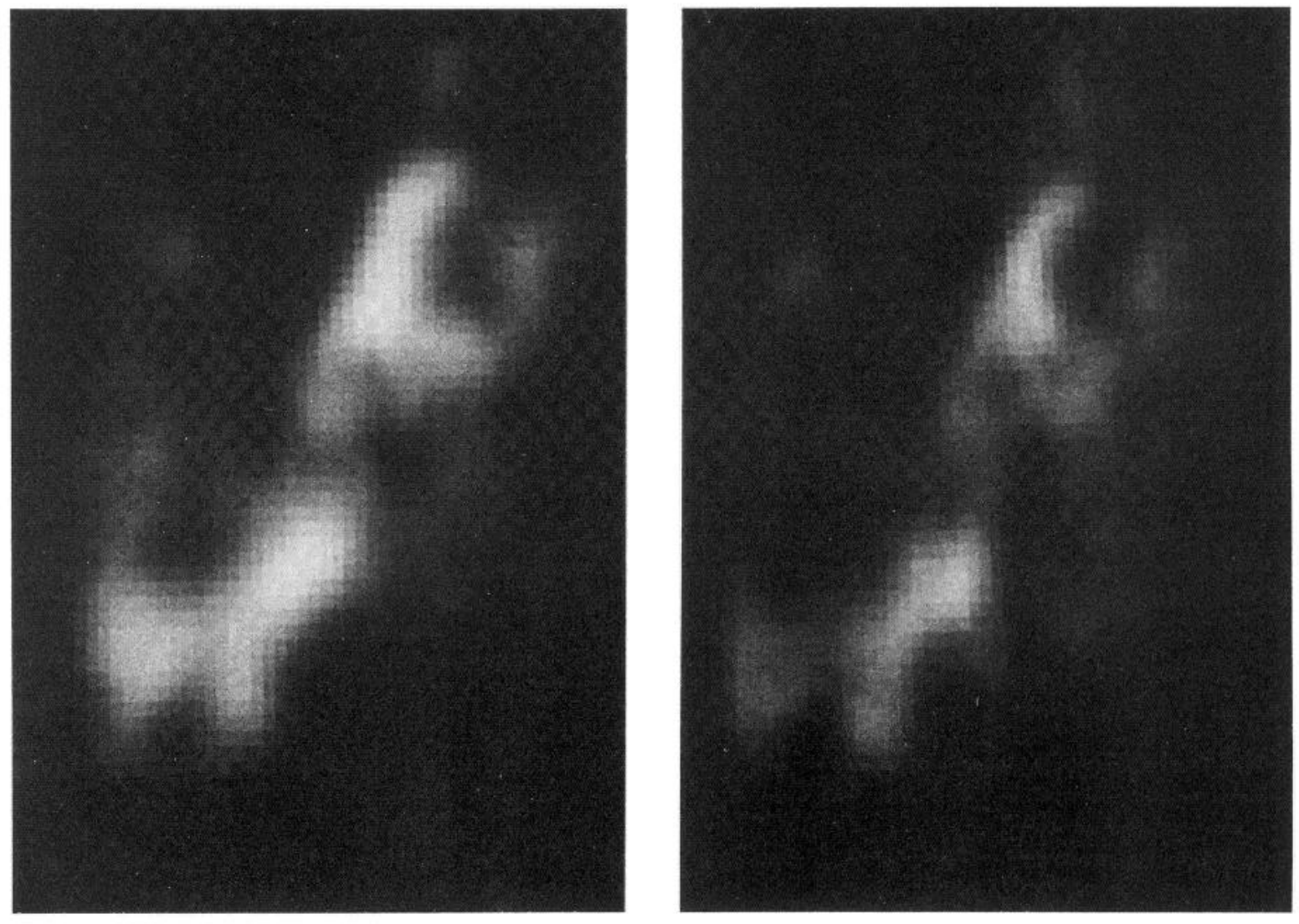

\section{$\mathrm{BTX}(\mathrm{Rh})$}

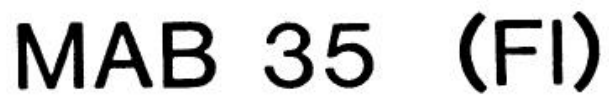

Figure 4. The same AChR patch labeled simultaneously with both R-BTX (left) and Mab 35 plus F-GAR (right). (See "Materials and Methods" for labeling protocols and filters employed.) The images were digitized and magnified to display the substructure of the patch. Although the intensity of the rhodamine $(R h)$ and fluorescein $(F /)$ signals are not equivalent, the distribution of labeled receptors appears the same. 


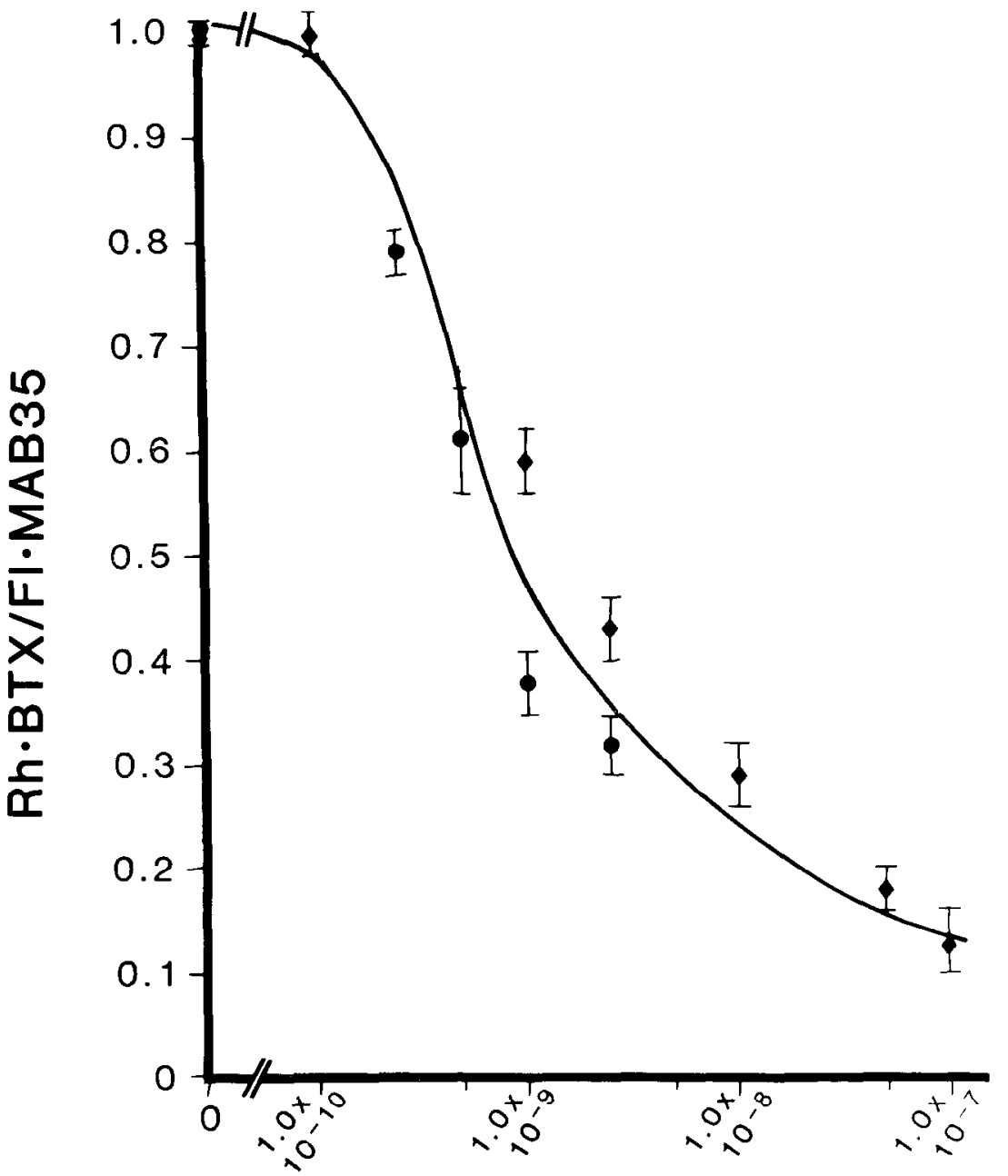

Figure 5. The sensitivity of the image analysis system. The total AChR pool was labeled with both R-BTX and Mab 35-F-GAR in the presence of increasing concentrations of native $\alpha$-BTX. The accuracy of the measurements is sufficient to permit distinction of $\sim 10 \%$ difference in fluorescence intensity. Bars $= \pm S E M$. Circles and diamonds represent two different cultures. Each point represents at least three NARPs.

\section{$(\alpha B T X), M$}

decrease in intensity of R-BTX fluorescence in the presence of increasing concentrations of unlabeled BTX. Changes of 10 to $15 \%$ were readily distinguished. The decrease in R-BTX fluorescence closely paralled the decrease in ${ }^{125}$-BTX binding measured under the same conditions (not shown). Therefore, we assume that R-BTX intensity is a sensitive index of the number of R-BTX-labeled receptors.

Most of the receptors within NARPs identified after $8 \mathrm{hr}$ of coculture were inserted into the surface membrane after the neurons were plated. The contribution of newly inserted receptors was even greater after 11 and $17 \mathrm{hr}$ (Table I). Essentially the same results were obtained whether R-BTX was used to label old receptors or new ones that appeared after the neurons were added. This is consistent with our conclusion based on fluorescence intensity (see "Materials and Methods") that the concentration of R-BTX used was indeed "saturating;" i.e., all exposed receptors were labeled after 1 $\mathrm{hr}$ at $37^{\circ} \mathrm{C}$. It also implies that R-BTX binds as tightly to AChHs as does unconjugated BTX. Since there was no significant difference in the two series, the results were pooled, and they are presented graphically in Figure 6.

To determine whether the ratio of new to total receptors at newly formed NARPs could be accounted for by the "basal" rate of receptor accumulation, surface receptors in uninnervated myotubes (no added neurons) were blocked with $\alpha$-BTX, and now roceptors subsequently incorporated in the surface membrane were assayed with ${ }^{125}$-BTX at various times thereafter. The results of three separate experiments (platings), expressed as a percentage of the initial surface population, are shown as open bars in Figure 6. At each point the values fall significantly below the percentage of newly inserted receptors observed at NARPs.

The increased rate of accumulation of new receptors at NARPS was not maintained indefinitely. We examined several cultures 3 days after adding ciliary neurons to the myotubes. All receptors were blocked with R-BTX or with unconjugated toxin, and the ratios of new to total NARP receptors were determined $8 \mathrm{hr}$ later. As shown in the last row of Table I and the dotted bar in Figure 6, the percentage of new receptors within the 3-day NARPs that appeared during the 8-hr interval was similar to that expected from the basal rate of receptor synthesis.

Receptor insertion at 3-day NARPs may contribute the same number of new receplors as at 8-hr NARPs but result in a lower proportion of new AChRs if the 3-day clusters contained a greater total receptor number. We examined this possibility by comparing the peak fluorescence intensity measurements at both 3-day and 8hr NARPS. In one series of experiments we compared the intensity of Mab 35-F-GAR-labeled NARPs after 3 days of nerve-muscle coculture with NARPs labeled $8 \mathrm{hr}$ after addition of the neurons. There was a wide variation in peak intensities among both 3-day and 8-hr NARPS, but within the range of fluorescence selected for the insertion/migration study, the average intensities were not significantly different ( $118 \pm 9$ arbitrary units; $N=21,3$ days; $125 \pm 10$; $N=19,8 \mathrm{hr}) .^{5}$

We also examined receptor density assessed from peak fluorescence intensity measurements at hot spots (receptor clusters not

${ }^{5}$ Throughout this study, only receptor clusters having a peak intensity greater than 2 times background were included. Thus, dim NARPs from both 8-hr and 3-day cultures were not examined. 
TABLE ।

Contribution of new receptors to neurite- and cell body-associated receptor patches and to receptor clusters not associated with neurons (hot spots) All cultures were prelabeled for $1 \mathrm{hr}$ either with R-BTX or with native BTX, and then neurons were added along with the complementary label (i.e., BTX or R-BTX, respectively) for the remaining period of co-culture except for the 3-day co-cultures which were labeled 3 days after neurons were plated. Data are mean percentage of new receptors \pm SEM. Entries at $8 \mathrm{hr}$ are based on 24 cultures (four platings); 11-hr entries are based on 12 cultures (two platings); and 17 -hr entries are based on 12 cultures (two platings).

\begin{tabular}{|c|c|c|c|c|c|}
\hline \multirow{2}{*}{$\begin{array}{l}\text { Time of } \\
\text { Co-culture }\end{array}$} & \multirow{2}{*}{$\begin{array}{l}\text { Time of } \\
\text { Postiabel }\end{array}$} & \multicolumn{2}{|c|}{ NARPS } & \multicolumn{2}{|c|}{ Hot Spots } \\
\hline & & R-BTX Prelabel & BTX Prelabel & R-BTX Prelabel & BTX Prelabel \\
\hline $8 \mathrm{hr}$ & $8 \mathrm{hr}$ & $\begin{array}{c}61.0 \pm 2.9 \\
(14)^{\mathrm{a}}\end{array}$ & $\begin{array}{c}61.6 \pm 4.6 \\
\quad(13)\end{array}$ & $\begin{array}{c}16.5 \pm 5.1 \\
(7)\end{array}$ & $\begin{array}{c}16.8 \pm 3.2 \\
(5)\end{array}$ \\
\hline $11 \mathrm{hr}$ & $11 \mathrm{hr}$ & $\begin{array}{l}72.4 \pm 4.2 \\
(7)\end{array}$ & $\begin{array}{c}77.8 \pm 8.3 \\
(7)\end{array}$ & $\begin{array}{c}26.3 \pm 5.7 \\
(6)\end{array}$ & $\begin{array}{c}31.2 \pm 4.7 \\
(6)\end{array}$ \\
\hline $17 \mathrm{hr}$ & $17 \mathrm{hr}$ & $\begin{array}{l}85.6 \pm 2.5 \\
(5)\end{array}$ & $\begin{array}{c}79.0 \pm 13 \\
(4)\end{array}$ & $\begin{array}{c}26.3 \pm 11.9 \\
(6)\end{array}$ & \\
\hline
\end{tabular}

${ }^{a}$ Numbers in parentheses, number of NARPS

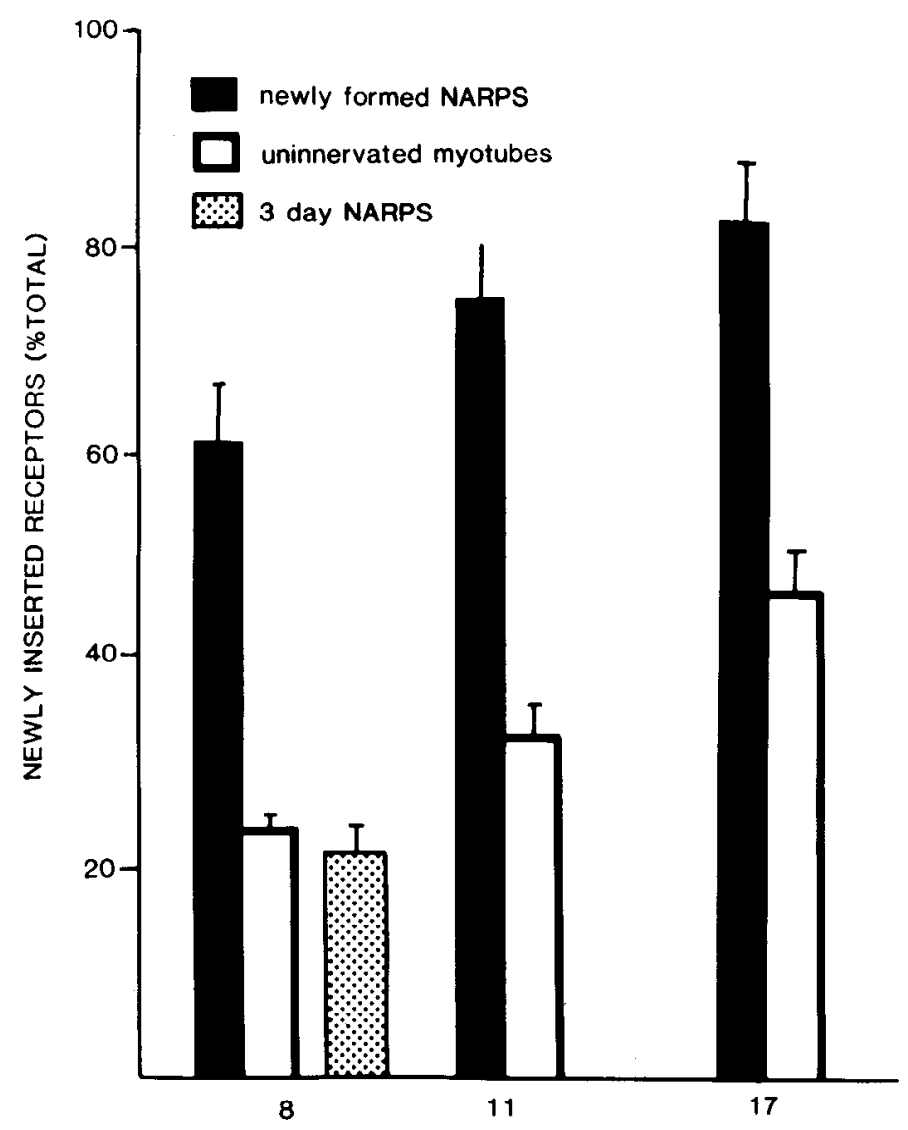

HOURS AFTER BTX PRE-LABEL

Figure 6. The contribution of new receptors to young NARPs, to established NARPs, and to the total surface pool in uninnervated myotubes. Results from R-BTX prelabel and native BTX prolabel cxpcriments (see Table 1) have been pooled. Receptors in uninnervated myotubes were assayed by 125-BTX binding.

associated with neurites or with perikarya) on contacted and noncontacted myotubes. Hot spots labeled with Mab 35 and F-GAR were at least as intense as similarly end-labeled NARPs (126 \pm 29 ; $N=7$ ), but the prelabel/end-label paradigm indicates that only about $17 \%$ of the hot spot receptors were inserted over the same 8-hr interval used to assay NARPs (Table I). The percentage of new receptors at hot spots increased somewhat over the next $9 \mathrm{hr}$, but at each time point it remained far below the percentage estimated at 8-hr NARPS.
The cell bodies of ciliary ganglion neurons often settled directly on top of myotubes, and many of these cell bodies were associated with patches of R-BTX fluorescence. On closer examination of a few "soma" contacts, foot-like processes ( $<10 \mu \mathrm{m}$ in length) were visible which may be the sites for the receptor accumulation. In contrast to the situation at newly formed NARPs along neurites, the receptor clusters at cell bodies detected after $8 \mathrm{hr}$ of co-culture were made up predominantly of pre-existing receptors. New receptors, determined as described above, amounted to only $17.6 \pm 5.2 \%(n=12)$ of the total. The accumulation of new receptors at hot spots and at cell body-associated receptor patches is close to that predictcd by the "normal" rate of receptor incorporation of $\sim 3 \% / \mathrm{hr}$ (see Fig. 6 , open bars). This is consistent with earlier reports that receptors within hot spots on uninnervated myotubes turn over at approximately the same rate as do diffusely distributed receptors (Axelrod, et al., 1976; Schuctzc ot al., 1978).

\section{Discussion}

Among the population of chick spinal cord cells, motoneurons are nearly unique in their ability to induce NARPs on contacted myotubes. Thus, secretory products, surface molecules, or other factors responsible for receptor aggregation are not shared by all neurons derived from the neural tube.

NARP induction may be characteristic of all cholinergic neurons. The motoneurons and ciliary ganglion cells studied here are, of course, cholinergic. In addition, neuroblastoma $\times$ glioma hybrid cells (Nelson et al., 1976), PC12 cells (Schubert et al., 1977), and rat sympathetic ganglion neurons (Nurse and O'Lague, 1975) grown under conditions that promote the synthesis of acetylcholine (ACh) are all capable of inducing NARPs on the surface of cultured myotubes. It is possible that only cholinergic neurons can promote AChR accumulation. The rare association between NARPs and nonmotoneurons in vitro does not necessarily violate this principle. This correspondence might be entirely due to chance as the frequency of non-motoneuron NARPs, $0.07 / 100 \mu \mathrm{m}$, is comparable to the frequency of hot spots along uninnvervated myotubes. It might also indicate that some of the non-motoneurons are cholinergic, i.e., those derived from the preganglionic column of Terni. NARPs form when neurons and myotubes are grown in the presence of $\alpha$-BTX or curare, so that ACh itself is probably not the inducing factor. Some other property, highly correlated with the cholinergic phenotype, must be involved.

NARPs are induced rapidly by ciliary ganglion neurons - perhaps at their advancing growth cones (Role et al., 1982). Other experiments have shown that the plateau in NARPs per neuron observed after 3 days coincides with the cessation of rapid neurite extension (L. W. Role and G. D. Fischbach, manuscript in preparation). At this 
time, either no NARPs are formed along neurites proximal to the endings or new NARPs replace old NARPs on a one-for-one basis.

Our estimates of the relative fluorescence intensity of prelabeled and end-labeled receptors indicate that, during the early stages of NARP formation, the contribution of newly inserted receptors is too great to be accounted for simply by the "basal" rate of reccptor insertion measured in uninnervated myotubes. It is conceivable that new receptors inserted at random into the surface membrane at the basal rate are preferentially mobilized and trapped at new NARPs. However, a more likely hypothesis is that the rate of new receptor insertion is increased in the immediate vicinity of young NARPs. This might come about in two ways. First, the local rate of receptor synthesis may be increased. In fact insertion closely parallels synthesis in uninnervated myotubes (Devreotes et al., 1977; Gardner and Fambrough, 1979). An intracellular precursor pool of AChRs does exist in chick myotubes, but it is "traversed" by newly synthesized receptors in $2 \mathrm{hr}$. or less (Devreotes et al., 1977). Second, it is possible that intracellular receptors synthesized at the control rate are channeled, in some way, toward new NARPs. The intracellular pool amounts to $10 \%$ of the total surface population. Accumulation of a small subset of this pool beneath NARPs could account for the increased rate of insertion.

We do not know the size of the myotube membrane domain influenced by neurites in regard to receptor accumulation. It may be that newly synthesized receptors are inserted over a relatively wide area and then mobilized to the synaptic site. NARPs observed during the first $24 \mathrm{hr}$ of co-culture are relatively large and contain several brightly fluorescent speckles, so that the area affected at early times may be larger than the zone of nerve-muscle contact. The area of increased AChR density at end plates in vivo is also larger than the nerve terminal arbor at the earliest times examined (Bevan and Steinbach, 1977; Jacob and Lentz, 1979; Slater, 1982). Another, less direct, observation that suggests a neurite influence beyond the contacl cone is the lact thal receplor aggregates located 50 to 100 $\mu \mathrm{m}$ away from neurite-muscle contacts on Xenopus myocytes and chick myotubes "break up" as new NARPs form (Anderson and Cohen, 1977; Frank and Fischbach, 1979; Moody-Corbett and Cohen, 1982; Kuromi and Kidokoro, 1984). In contrast, our finding that the rate of receptor incorporation into hot spots on innervated fibers is approximately equal to that expected from the basal rate of receptor insertion suggests that the nerve's influence does not extend over the entire myotube surface. In some cases, hot spots were located within $200 \mu \mathrm{m}$ of a NARP. Experiments designed to locate intracellular receptors on the ultrastructural level suggest that insertion of induced receptors may be extremely focal. Myoplasmic coated vesicles which contain AChRs and which appear to be en route to the cell surface are concentrated immediately beneath membrane receptor aggregates in brain extract-treated myotubes (Bursztajn and Fischbach, 1984). Although we hypothesize that brain extract mimics the effect of cholinergic neurites, more direct, electron microscopic data are needed at identified NARPs and the surrounding area.

Our estimates of receptor insertion in uninnervated cultures of $3 \% / \mathrm{hr}$ are slightly lower than those reported by Devreotes and Fambrough (1975) (4 to 5\%/hr). These authors also studied chick myotubes, but subtle differences in plating density (and hence in degree of myoblast fusion), culture medium, or temperature might account for the disparity. Our measurements were made in cultures grown under conditions that were identical, save for the presence of neurons, to those used for fluorescence measurements.

It might be argued that our estimates of old receptors at NARPS are low because BTX slows the rate of receptor migration. Indeed, there is a 50 -fold disparity in estimates of receptor diffusion coefficient based on fluorescence photobleaching recovery curves of $\mathrm{R}$ BTX-labeled rat myotube receptors $\left(5 x^{-11} \mathrm{~cm}^{2} / \mathrm{sec}\right.$; Axelrod et al., 1976) and on recovery of ACh sensitivity in Xenopus myocytes (2.5 $\times 10^{-9} \mathrm{~cm}^{2} / \mathrm{sec}$; Poo, 1982; Young and Poo, 1983). This might reflect toxin drag, but it might also reflect a species difference in membrane fluidity. In any case, the fact that NARPs labeled with Mab 35 in toxin-treated cultures were as intense as Mab 35-labeled NARPs in control cultures without toxin argues against slow migration of liganded receptors. In addition, the presence of toxin did not prevent receptor aggregation at cell bodies over a period of $8 \mathrm{hr}$.

In contrast, we undoubtedly have underestimated the rate of appearance of new receptors at NARPs because of our selection of time zero. It takes 2 to $3 \mathrm{hr}$ for ciliary ganglion neurons to settle and extend a process for more than $50 \mu \mathrm{m}$, (L. W. Role and G. D. Fischbach, manuscript in preparation), the minimum soma-to-NARP distance included in this study. Thus the " $8 \mathrm{hr}$ " point more realistically corresponds to a 5- to 6-hr interval after first meaningful contact. This consideration, taken together with the fact that receptors do not emerge on the surface for $2 \mathrm{hr}$ after they are synthesized, suggests that the initial, induced rate of receptor addition near NARPs may be 4 to 5 times the background basal rate of insertion.

We do not know how long the "burst" of receptor insertion lasts. Aller $17 \mathrm{hr}$ of co-culture, new receptors comprised $85 \%$ of the total NARP complement. The increment $(20 \%)$ over the value observed after $8 \mathrm{hr}$ seems small, but two considerations suggest that it significantly underestimates the rate of receptor insertion in the 8- to 17-hr interval. First, NARPs continue to form for at least $48 \mathrm{hr}$ under our culture conditions (Role et al., 1983); therefore, some NARPs examined at $17 \mathrm{hr}$ may have been quite "young." Indeed, the distribution of the percentago of now NARP receptors was wider between 8 and $17 \mathrm{hr}$ (53 to 100\%) than at earlier or later times. Time lapse studies of individual NARPs would settle this issue. Second, as the number of new receptors increases with time, the rate of degradation of new receptors becomes significant, causing a disparily between inserlion and accurnulation. The rate of appearance of new receptors at NARPs must decline at some time between $17 \mathrm{hr}$ and 3 days of co-culture. In 3-day co-cultures the percentage of new receptors that appear at NARPs within an 8-hr interval is no greater than that observed at uninnervated hot spots. At this time, it is comparable to that expected from the basal rate of receptor insertion.

We have emphasized the accumulation of newly insertcd receptors at young NARPS, but it is clear that "old" receptors present in the membrane before the arrival of the nerve contribute as well. Accumulation of prelabeled receptors, clearly above the background level, were observed at all NARPs examined after $8 \mathrm{hr}$ of co-culture. A mechanism must exist for aggregating and trapping receplors al newly formed synapses (cf. Nitkin et al., 1983). A recent study of embryonic rat spinal cord intercostal muscle organ cultures (ZiskindConhaim et al., 1984) emphasized the migration of receptors to developing endplates. Receptors labeled (with ${ }^{125} \mathrm{I}-\mathrm{BTX}$ ) at the time of explantation (embryonic day 15) comprised the majority of the endplate complement $24 \mathrm{hr}$ later. It is difficult to compare this result obtained in a different species, after $24 \mathrm{hr}$ at $31^{\circ} \mathrm{C}$, with our own data obtained at earlier times (i.e., $8 \mathrm{hr}$ ) at $37^{\circ} \mathrm{C}$, but they are not inconsistent.

Even at early times (within the first $24 \mathrm{hr}$ of co-culture), old receptors predominate within receptor clusters beneath or near cell bodies. This striking difference between soma-myotube and neuritemyotube contacts was unexpected. If a soluble neuronal factor is responsible for induction of receptor insertion, then either it is present at low concentration in cell bodies, or it is not released from this site. In any case, it seems advisable to distinguish perisomal AChR clusters from NARPs.

In summary, we conclude that NARP formation is a complex affair. At early times newly inserted receptors predominate along neurites, but the relative contribution of receptor synthesis and receptor migration may vary with time and with position along the cell bodyneurite axis. Probably more than one "factor" is involved and purification schemes must take this complexity into account. 


\section{References}

Anderson, M. J., and M. W. Cohen (1977) Nerve-induced and spontaneous redistribution of acetylcholine receptors on cultured muscle cells. J. Physiol. 268: 757-773.

Anderson, M. J., M. W. Cohen, and E. Zorychta (1977) Effects of innervation on the distribution of acetylcholine receptors on cultured cells. J. Physiol. (Lond.) 268: 731-756.

Axelrod, D., P. Ravdin, D. E. Koppel, J. Schlessinger, W. W. Webb, E. L. Elson, and T. R. Podleski (1976) Lateral motion of fluorescently labeled acetylcholine receptors in membranes of developing muscle cells. Proc. Natl. Acad. Sci. U. S. A. 73: 4594-4598

Bevan, S., and J. Steinbach (1977) The distribution of bungarotoxin binding sites on mammalian skeletal muscle developing in vivo. J. Physiol. (Lond.) 267: 195-213

Buc-Caron, M. -H., P. Nystrom, and G. D. Fischbach (1983) Induction of acetylcholine receptor synthesis and aggregation: Partial purification of low molecular weight activity. Dev. Biol. 95: 378-386.

Bursztajn, S., and G. D. Fischbach (1984) Evidence that coated vesicles transport acetylcholine receptors to the surface membrane of chick myotubes. J. Cell Biol. 98: 498-506.

Christian, C. N., M. P. Daniels, H. Sugiyama, Z. Vogel, L. Jacques, and P. G. Nelson (1978) A factor from neurons increases the number of acetylcholine receptor aggregates on cultured muscle cells. Proc. Natl. Acad. Sci. U. S. A. 75: 4011-4015

Cohen, M. W., and P. R. Weldon (1980) Localization of acetylcholine receptors and synaptic ultrastructure at nerve-muscle contacts in culture: Dependence on nerve type. J. Cell Biol. 86: 388-401.

Cohen, S. A. (1980) Early nerve-muscle synapses in vitro release transmilter over postsynaptic membrane having low acetylcholine sensitivity. Proc. Natl. Acad. Sci. U. S. A. 77:644-648

Devreotes, P., and D. Fambrough (1975) Acetylcholine receptor turnover in membranes of developing muscle fibers. J. Cell Biol. 65: 335-358.

Devreotes, P., J. M. Gardner, and D. M. Fambrough (1977) Kinetics of biosynthesis of acetylcholine receptor and subsequent incorporation into plasma membrane of cultured chick skeletal muscle. Cell 10:365-373

Fischbach, G. D. (1972) Synapse formation between dissociated nerve and muscle cells in low density cell cultures. Dev. Biol. 28: 407-429.

Fischbach, G. D., and S. A. Cohen (1973) The distribution of acetylcholine sensitivity over unimervated and innervaled muscle fibers grown in cell cultures. Dev. Biol. 31: 147-162.

Fischbach, G. D., L. W. Role, R. J. O'Brien, and V. Mattosian (1984) The contribution of new and old AChR's to newly formed postsynaptic receptor aggregates. Soc. Neurosci. Abstr. 10: 925.

Frank, E., and G. D. Fischbach (1979) Early events in neuromuscular junction formation in vitro. J. Cell Biol. 83: 143-158.

Gardner, J. M., and D. M. Fambrough (1979) Acetylcholine receptor degradation measured by density labeling: Effects of cholinergic ligands and evidence against recycling. Cell 16: 661-674.

Jacob, M., and T. L. Lentz (1979) Localization of acetylcholine receptors by Imearls of horseradish peroxidase- $\alpha$-bungarotoxin during formation and development of the neuromuscular junction in the chick embryo. J. Cell Biol. 82: 195-211.

Jessell, T. M., R. E. Siegel, and G. D. Fischbach (1979) Induction of acetylcholine receptors on cultured skeletal muscle by a factor extracted from brairi and spinal cord. Proc. Natl. Acad. Sci. U. S. A. 76: 5397-5401.

Kidokoro, $Y$., and $E$. Yeh (1982) Initial synaptic transmission at the growth cone in Xenopus nerve-muscle cultures. Proc. Natl. Acad. Sci. U. S. A. 79: 6727-6731

Kuromi, H., and Y. Kidokoro (1984) Nerve disperses pre-existing acetylcholine receptor cluslers prior to induction of receptor accumulation in Xenopus muscle cultures. Dev. Biol. 103: 53-61.

McPheeters, M., and L. M. Okun (1980) Identification and isolation in vitro of presumptive motoneurons marked by retrograde transport of a new fluorescent tracer. Soc. Neurosci. Abstr. 6:733.

Moody-Corbett, F., and M. W. Cohen (1982) Influence of nerve on the formation and survival of acetylcholine receptor and cholinesterase patches on embryonic Xenopus muscle cells in culture. J. Neurosci. 2 . 633-646.

Nelson, P., C. Christian, and M. Nirenberg (1976) Synapse formation between clonal neuroblastoma $\times$ glioma hybrid cells and striated muscle cells Proc Natl Acad. Sci. U. S. A. 73: 123-127.

Nishi, R., and D. Berg (1977) Dissociated ciliary ganglion neurons in vitro Survival and synapse formation. Proc. Natl. Acad. Sci. U. S. A. 74:51715175.

Nitkin, R. M., B. G. Wallace, M. E. Spira, E. W. Godfrey, and U. J. McMahan (1983) Molecular components of the synaptic basal lamina that direct differentiation of regenerating neuromuscular junctions. Cold Spring Harbor Symp. Quant. Biol. 48: 653-665.

Nurse, C., and P. O'Lague (1975) Formation of cholinergic synapses between dissociated sympathetic neurons and skeletal myotubes of rat in cell culture. Proc. Natl. Acad. Sci. U. S. A. 72: 1955-1959.

Okun, L. M. (1981) Identification and isolation in vitro of neurons marked in situ by retrograde transport. In 1981 Short Course Syllabus: New Approaches in Developmental Biology, D. Gottlieb, ed., Society for Neuroscience, Bethesda, MD.

Orida, N., and Poo, M. (1978) Electrophoretic movement and localization of acetylcholine receptors in the embryonic muscle membrane. Nature 275 31-35

Podleski, T. R., D. Axelrod, P. Ravdin, 1. Greenberg, M. M. Johnson, and M. Salpeter (1978) Nerve extract induces increase and redistribution of acetylcholine receptor aggregates on cultured muscle cells. Proc. Natl. Acad Sci. U. S. A. 75: 2035-2039.

Poo, M. -M. (1982) Rapid lateral diffusion of functional ACh receptors in embryonic muscle cell membrane. Nature 295: 332-334.

Ravdin, P., and D. Axelrod (1977) Fluorescent tetramethyl rhodamine deriv atives of $\alpha$-bungarotoxin: Preparation, separation and characterization. $\wedge$ nal. Biochom. 58: 585592 .

Role, L. W., R. I. Hume, and G. D. Fischbach (1982) Transmitter release and receptor aggregation at ciliary neuron-muscle synapses. Soc. Neurosci. Abstr. 8: 129

Role, L. W., D. Roufa, and G. D. Fischbach (1983) Transmitter release and presynaptic specialization at nerve-muscle contacts in vitro. Soc. Neurosci Abstr. 9: 1179 .

Schubert, D., S. Heinemann, and Y. Kidokoro (1977) Cholinergic metabolism and synapse formation by a rat nerve cell line. Proc. Natl. Acad. Sci. U. S. A. 74: 2579-2583.

Schuetze, S. M., E. F. Frank, and G. D. Fischbach (1978) Channel open time and metabolic stability of synaptic and extrasynaptic acetylcholine receptors on cultured chick myotubes. Proc. Natl. Acad. Sci. U. S. A. 75: 520523.

Slater, C. (1982) Neural influence on postnatal changes in acetylcholine receptor distribution at nerve-muscle junctions in the mouse. Dev. Biol. 94: 23-30.

Stewart, W. (1981) Lucifer dyes, highly fluorescent dyes for biological tracing Nature 292: 17-21.

Young, S. H., and M. -M. Poo (1983) Rapid lateral diffusion of extrajunctional acetylcholine receptors in the developing muscle membrane of Xenopus tadpole. J. Neurosci. 3: 225-231.

Ziskind-Conhaim, L., I. Geffen, and Z. W. Hall (1984) Redistribution of acetylcholine receptors on developing rat myotubes. J. Neurosci. 4: 23462349. 